\title{
Specific features of protein biosynthesis in higher eukaryotes
}

\author{
A. V. El'skaya, B. S. Negrutskii, V. F. Shalak, A. A. Vislovukh, D. O. Vlasenko,
}

\author{
A. V. Novosylna, T. O. Lukash, M. V. Veremieva
}

Institute of Molecular Biology and Genetics, NAS of Ukraine

150, Akademika Zabolotnogo Str., Kyiv, Ukraine, 03680

elskaya@imbg.org.ua

\begin{abstract}
Over 40 years of studies in the field of higher eukaryotic translation are summarized in the review. Among the pioneer results obtained we should especially accentuate the following: $i$ ) discovery of the adaptation of tRNAs and aminoacyl-tRNA synthetases (ARSs) cellular pools to the synthesis of specific proteins and modulation of the elongation rate by rare isoacceptor $T R N A s$; ii) the chaperone-like properties of the translation components (ribosomes and elongation factor eEF1A); characterization of high molecular weight complexes of ARSs; iii) functional compartmentalization, including channeling of tRNA in eukaryotic cells; iv) molecular mechanisms of channeling mediated by different non-canonical complexes involving eEF1A, $t R N A$ and aminoacyl-tRNA synthetases; v) characterization of the crystal structure of eEF1A2; vi) comparison of spatial structure, molecular dynamics, tyrosine phosphorylation and abilities to interact with different protein partners of the eEF1A1 and eEF1A2 isoforms; vii) discovery of the microRNA-mediated control of the expression of the proto-oncogenic eEF1A2 isoform in cancer cells; viii) examination of the cancer-related changes in translation elongation complex eEF1H and mechanisms of oncogene PTI-1 action; ix) discovery of the third tRNA binding site on mammals ribosomes and the allosteric interaction of the $80 S$ ribosomal $A$ and $E$ sites.
\end{abstract}

Keywords: protein biosynthesis, higher eukaryotes, $t R N A$, aminoacyl-tRNA synthetases, compartmentalization, channeling, eEF1A, microRNAs, eEF1H, PTI-1, 80S ribosomes.

Protein biosynthesis is a major cellular process providing decoding and realization of genetic information. In general it is an intrinsic attribute of all living organisms and has common characteristics. However, from the very beginning the main translational components and molecular mechanisms were studied solely on prokaryotic objects. Nowadays, it is clear that in spite of the common overall picture of protein biosynthesis there are some specific peculiarities of the process in higher eukaryotes.

We had started to investigate the molecular mechanisms of translation of genetic information on mammalian objects 40 years ago with a focus on tRNA and aminoacyl-tRNA synthetases (ARSs). First, we were interested whether a set of tRNAs and ARSs, $i$. e. a ratio of

(C) Institute of Molecular Biology and Genetics, NAS of Ukraine, 2013 individual molecules in a total cellular pool, is constant or variable depending on the cell functioning and physiological or pathological conditions of an organism subsistence. One of the appropriate model systems to study this question was considered the mammary gland which undergoes striking structural and functional changes. Consequently, in full lactation period protein synthesis in the mammary gland is extraordinary rapid and intensive and mainly two specific milk proteins are produced. A comparison of tRNA and ARS pools in mammary gland of virginal, lactating and non-lactating cows resulted in discovery of so called «functional adaptation of tRNA and ARS to the synthesis of specific proteins» [1-3]. The essence of this phenomenon is that at full lactation the ratio of some individual tRNA and ARS changes to correspond to the amino acid composition the main milk proteins. Moreover, we had found the 
changes in isoacceptor spectrum of individual tRNAs as well, e. g. the appearance of a new minor component of leucyl-tRNAs during the production of the specific proteins, which disappears in the dry period. Since publication of our pioneer results indicating the tRNA functional adaptation, the phenomenon was described for several other specialized tissues not only in mammals $[4,5]$. Later, it was found that tRNA and ARS adaptation was of great importance for regulating the intensity and rate of certain protein production. Moreover, the appearance (or considerable raise) of some isoacceptor species of tRNA may switch on the translation of mRNA containing some rare codon corresponding to the anticodon of this individual tRNA. So called «adaptor-modification» hypothesis of protein biosynthesis regulation at the translation level was proposed on the basis of such data and experimentally proved $[4,5]$.We had managed to demonstrate the regulatory function of tRNA using tRNA-dependent cell-free system of protein biosynthesis and tissue explants from lactating rabbit mammary gland [6]. The level and rate of both total protein and caseins synthesis were much higher in the presence of homologous tRNA from lactating gland in comparison with tRNA from dry mammary, rabbit liver or yeast. Moreover, the stimulation of specific milk proteins production was observed under addition of tRNA from lactating gland to the incubation medium with the gland explants of pregnant rabbits.

The basic principles of gene expression control in higher eukaryotes at the translation level were formulated in the review [7] devoted to the facts and hypotheses of protein synthesis regulation in higher eukaryotes. Special attention was paid to the translation regulation as one of the most important components of changing or interfering with the cell program in such processes as growth, development, malignant transformation, and apoptosis.

The situation with ARSs is similar, their synthesis and amount in eukaryotic cells is not constitutive and not synchronized depending on the functional state of an organism and physiological or pathological conditions of its operation. Thus, the adaptation of ARS pool to the amino acid composition of mainly synthesized proteins was found at the differentiation of mammary gland and in regenerating liver [8-10]. Moreover, some particular alterations were shown for leucyl-tRNA synthetase (LeuRS) in differentiated (lactating) mammary gland. Today we may assume that the increase in amount and catalytic activity of the enzyme is connected not only with a high content of leucine in milk proteins but also with the fact that LeuRS according to recent data is a leucine sensor for TORC1 in both yeast and mammalian cells [11]. It is well known that TORC1 is a central regulator of cell growth in response to amino acid availability.

It is of great interest that study on mammalian ARSs opened a new phase in our research on structural and functional organization of the translation apparatus as a whole unit and consequently on compartmentalization of protein biosynthesis in higher eukaryotes. The existence of multisynthetase complexes, affinity of essentially all ARSs to the ribosomal RNA, linkage of various translational components with the cytoskeleton and endoplasmic reticulum evidence specific organization of protein synthesis apparatus as a basis for compartmentalization of protein biosynthesis in higher eukaryotes. On this account several directions of experimental investigations were developed by us, namely - study on large ARSs complexes, tRNA/aatRNA channeling and interactions of ARS with ribosome and elongation factor eEF1A. We studied large ARSs complexes (codosomes or high- $\mathrm{M}_{r}$ ), first described by Deutscher [12], in different mammalian tissues under different conditions and found that codosomes contained not only majority of ARSs but methyltransferase, protein kinases activities, tRNA and several phospholipids as well [13-16]. Importantly, there were not found protease and ribonuclease activities. The composition of high- $\mathrm{M}_{r}$ complexes at different intensity and rate of protein synthesis corresponded in general to the total cytoplasmic pool of their constituents which seems to reflect the principles of large complexes formation.

The high- $\mathrm{M}_{r}$ complexes are associated inside the cell with rough endoplasmic reticulum and polyribosomes. It is suggested that the affinity of the eukaryotic ARSs to high-molecular weight rRNA serves their localization on polyribosomes [17]. The association of ARS with polyribosomes is rather labile and is shown to change at the functional and pathological states that differ in the intensity of protein synthesis in the eukaryotic cell [18]. The association of the higher eukaryotic ARSs, initiation and elongation factors with polyribosomes and membranes seems to enable the compartmentalization of 
the translational machinery, thereby enhancing the efficiency of its operating.

A question arose as to the functional role of the ARSs association with polyribosomes. Some results were reported indicating the influence of ribosomes on the catalytic activity of ARS, however, these data were rather contradictory and fragmentary. We provided more detailed investigation of the functional meaning of the ARS-ribosome interaction and discovered the undoubted effect of rabbit liver ribosomes on the catalytic properties and thermal stability of homologous LeuRS, involved in the high- $\mathrm{M}_{r}$ complex, and phenylalanyltRNA synthetase (PheRS) which is not a component of this complex. Study on thermal stability gave us ground to think that $80 \mathrm{~S}$ ribosomes could stabilize an active conformation and promote the renaturation of the mammalian ARSs.

This line of research was explored further in longstanding collaboration with Marc Mirande's group. Subcellular localization of the multi-aminoacyl-tRNA synthetase complex (MARS) in human cells was examined. The cellular mobility of several synthetases, assessed by measuring fluorescence recovery after photobleaching, demonstrated that they are not freely diffusible within the cytoplasm. Several of these enzymes, isolated by tandem affinity purification, were co-purified with ribosomal proteins and actin. The capacity of ARSs to interact with polyribosomes and with the actin cytoskeleton was shown to impact their subcellular localization and mobility [19]. Evolutionary aspects of multisynthetase complex formation were studied taking as an example Nematoda Caenorhabditis elegans [20]. This organism was shown to evolve a specific structural organization of this complex, which contains several components of the MARS complexes known so far, but also displays significant variations. These data highlight molecular evolution events that took place after radiation of bilaterians. Remarkably, it shows that expansion of MARS assembly in metazoans is not linear, but is the result of additions and subtractions along evolution.

Another translational component the ARS interaction with which is of special importance is elongation factor $1 \mathrm{~A}$ (eEF1A) and the meaning of such relationship is closely related to the tRNA channeling, which was discovered during stay of B. Negrutskii in the laboratory of prof. Deutscher [21]. It appeared that protein biosynthesis in mammalian cells is a channeled pathway - aa-tRNA, the intermediate in the process, is directly transferred from ARS to the elongation factor, and then to ribosome without dissociation into cellular fluid [22]. It was revealed that aa-tRNA and tRNA were never free in the cytoplasm of the eukaryotic cell $[21,22]$. In our research, first of all, we found that rabbit eEF1A could stimulate the phenylalanyl-tRNA synthetase activity, the effect being specific towards the origin of tRNA and elongation factor molecules [23].

Later it was confirmed for other ARSs, moreover, in addition to activation eEF1A was shown to promote the renaturation of ARSs and protect them against denaturation $e$. $g$. by dilution [24]. Remarkably, in vitro renaturation was observed at the molar ratio of eEF1A to ARS equivalent to that found in the cytoplasm of higher eukaryotic cells. We suggested a direct interaction between these two key translational components and concluded that the chaperone-like activity of eEF1A might be important for maintaining the enzymes activity and stability in the protein synthesis compartments of mammalian cells. Furthermore, according to the proposed scheme of channeling, ARS and eEF1A are the partners ensuring the transport of tRNA/aa-tRNA from ARS to the factor, then to the ribosomal A site and from $\mathrm{E}$ site via the factor back to ARS to be re-aminoacylated. If our hypothesis was correct eEF1A should interact not only with ARS but with both free and charged tRNA rather strongly.

Eukaryotic EF1A was well known to interact in GTPbound form with aa-tRNA promoting its binding to the ribosome. However, another ternary complex [eEF1A. GDP - deacylated tRNA], had never been considered in widely recognized elongation schemes. We postulated the formation of this unusual complex in [23], and later detected it by four independent methods [25].

The formation of eEF1A - GDP - tRNA complex was shown for several non-charged individual tRNAs, and $K_{d}$ of the complexes were calculated. Of interest is a relatively high affinity of eEF1A to deacylated tRNAs in comparison with the prokaryotic system. No complexes were formed between any tRNA of different origin with prokaryotic EF1A. To check the universality of formation of non-orthodox complexes for eukaryotes the possibility of their formation of yeast and rabbit eEF1A - GDP with several deacylated tRNAs was stu- 


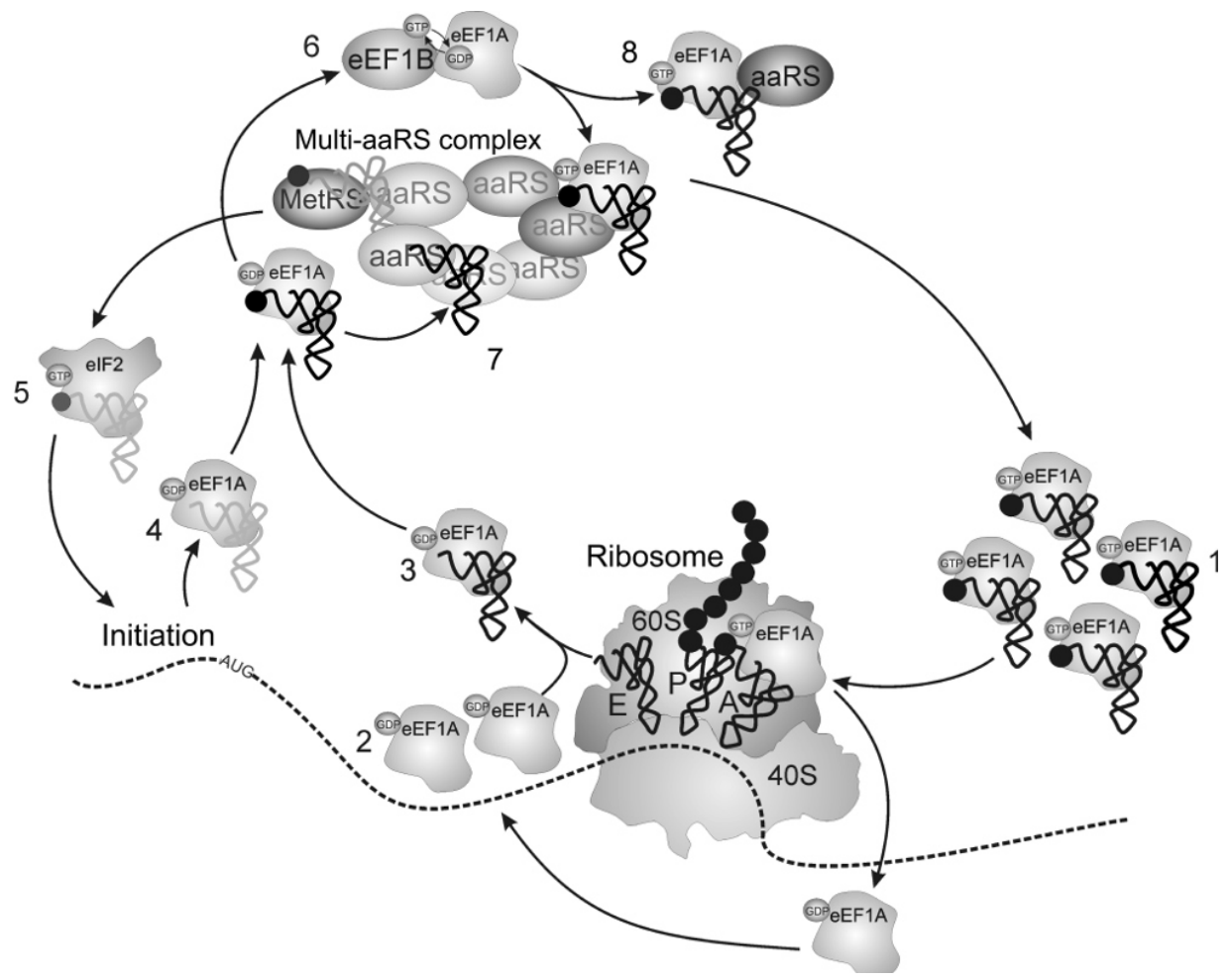

Channeling of initiator and elongator tRNAs for higher eukaryotic protein synthesis: 1 - formation of ternary complex aminoacyl-tRNA - eEF1A · GTP; 2 eEF1A - GDP is formed after GTP hydrolysis; 3 - eEF1A - GDP interacts with deacylated tRNA; 4 eEF1A - GDP can pick up deacylated initiator tRNA after the initiation step is completed; 5 - initiator methyonyl-tRNA can be channeled to the initiation site by eIF2 - GTP; 6 - eEF1B exchanges GDP for GTP in eEF1A molecule; 7 - aminoacyl-tRNA is synthesized by aminoacyltRNA synthetase; 8 - aminoacyl-tRNA is transferred from aminoacyl-tRNA synthetase to eEF1A · GTP

died by a band shift assay and confirmed by a FRET fluorescence technique. For the first time we have shown the ability of yeast eEF1A - GDP to form non-canonical ternary complex with deacylated tRNAs. It is of great interest that eukaryotic eEF1A - GDP can also form complex with deacylated initiator tRNA with stability equal to that of the complex with elongator tRNAs. Moreover, it was demonstrated the principal possibility of high affinity association between translation initiation factor eIF2 - GDP with deacylated initiator $\mathrm{tRNA}_{i}^{\mathrm{Met}}$. These data altogether strongly support the idea of universality of molecular mechanisms of aa-tRNA/tRNA channeling in protein synthesis in eukaryotic cells.

The channeling presumes transfer of a substrate «from hand to hand», in case of tRNA from ARS to eEF1A and vice versa. Does it mean that the active partners of the channeling process interact with each other directly? The possibility of ARS-EF1A interaction was studied in vitro using rabbit liver eEF1A, PheRS and valyltRNA synthetase (ValRS)-eEFlH complex. eEF1A caused 2-fold stimulation of both ValRS and PheRS formation. The stimulation was rather specific since BSA and bacterial factor EF-Tu had no stimulatory capacity. Nevertheless, the mechanisms of eEF1A-induced stimulation were quite different for two synthetases. Stimula- tion of ValRS required GTP strongly suggesting the classical ternary complex ValRS-GTP-eEF1A involvement [26]. On the contrary, activation of PheRS can be induced by GDP form of eEF1A as well [23]. Moreover, the stimulatory effect was observed already at the level of phenylalanine activation, suggesting factor-synthetase interaction to occur at some step before aminoacyl-tRNA dissociation. It gives grounds to propose a special functional role for eEF1A - GDP, namely, to form eEF1 - GDP. tRNA complex and to deliver deacylated tRNA to ARS. The idea was confirmed by obtaining the quaternary complexes of two spesifisities - [PheRS - EF-1A · GDP . tRNA $^{\text {Phe }}$ ] and [SerRS $\cdot$ EF-1A - GDP $\cdot$ tRNA $^{\text {Ser }}$ using «band shift» technique [27].

On the basis of these findings a model of translation apparatus functioning is developed which suggests eEF1A to be a shuttle between ribosome and hypotetic macromolecular complex of ARSs and eEF1H [28, 29].

In summary, the concept of functional compartmentalization of mammalian translation apparatus has been put forward. Functional compartmentalization is the formation of labile protein-protein and proteinRNA complexes which provide organization of the translation compartments and their efficient functioning, in particular, tRNA channeling. The definition for 
translational compartment is as follows: it is an assembly of macromolecular complexes which are dynamically converted during mRNA translation in some limited space [29]. The proposed scheme of tRNA channelling as a main feature of the protein synthesis compartment is given in Figure.

Besides the specific function of eEF1A in translation the factor is known as a moonlighting protein participating in many important cellular processes [28]. It is an actual challenge to understand the molecular basis of multifunctional behavior of eEF1A and interaction with many partners of different nature.

Structural studies on prokaryotic EF1A (formerly EF-Tu) involved in the various complexes with GDP or GTP/GDPPNP, aa-tRNA, and the exchange factor EF1B have provided an almost complete understanding of the molecular details of the EF1A functioning beyond the ribosome. The crystal structure of the protein complexed with GDP is known for trypsin-modified and native EF1A. The EF1A molecule consists of three distinct globular domains, connected by flexible interconnecting peptides, like beads on a string. The three domains form a flattened triangular shape of 7.5 by 5.0 by $3.0 \mathrm{~nm}$.

$\mathrm{X}$-ray data have been published for the yeast eEF1A (molecular mass $50 \mathrm{kDa}$ ) crystallized in a complex with a fragment of the nucleotide-exchanging subunit eEF1B $\alpha$ (molecular mass $11 \mathrm{kDa}$ ) [30]. As expected, eEF1A contained three structural domains similar to bacterial EF1A. Until we have recently obtained and resolved the crystal structure of rabbit liver EF1A [31] there was no information on the crystal or solution structure of mammalian eEF1A. It was not known how the conformation of eEF1A may be affected by its interaction with tRNA either. To address the issues, we analyzed the structure of both rabbit liver eEF1A - GDP and its complex with tRNA in solution by the neutron scattering and microcalorimetry methods. We found that rabbit liver eEF1A had a considerably more disordered conformation than its prokaryotic analogue. The conformation of eEF1A became significantly more compact during the interaction with tRNA [32]. The eEF1A molecule was hypothesized to adopt an extended conformation due to the loss of the association between domains I and III. The interaction was renewed upon addition of the biological ligand (tRNA) leading to significant compactization of the protein.
However, for a complete picture we needed a crystal structure of the factor. It is necessary to remind that two tissue- and development-specific isoforms of eEF1A have been identified, the properties of eEF1A1 and eEF1A2 will be thoroughly discussed below. In 2012 for the frst time, in collaboration with laboratory of prof. M. Tukalo we successfully crystallized one of the isoforms of mammalian factor [31], and investigated the crystal structure of the naturally folded and post-translationally modified eEF1A2 - GDP complex from rabbit liver (Oryctolagus cuniculus) at $2.6 \mathrm{C}$ resolution. Importantly, this complex is $100 \%$ identical to its human homologue. The overall structure of eEF1A2 - GDP is typical for the EF-Tu/EF1A family, however, several unique structural features of eEF1A2 - GDP comparing to eubacterial and archaebacterial analogs are demonstrated. The principal difference between the mechanisms of the GDP/ GTP exchange in the prokaryotic and higher eukaryotic elongation factors are described in details (in preparation). Further research will show whether the isoform eEF1A1 differs from eEF1A2 in this respect and how much if YES.

Two isoforms of eEF1A are about $98 \%$ similar though encoded by different genes with different expression patterns. The expression of the isoforms is mutually exclusive: eEF1A1 is expressed in all tissues throughout development but is absent in adult muscle and heart. The latter tissues express instead eEF1A2 as do certain other cell types including, notably, large motor neurons, islet cells in the pancreas and enteroendocrine cells in the gut. Since eEF1A2 is present in skeletal myocytes, cardiomyocytes and neurons and eEF1A1 in all remaining cells of the adult organism [33] a role of the isoforms in translation should be principally the same while tissue specific localization suggests a possibility of their different moonlighting functions. The most significant difference is connected with participation of the factor's isoforms in the essential cellular processes, while eEF1A2 is related to carcinogenesis, eEF1A1 is found to stimulate apoptosis [34]. eEF1A2 is found to be overexpressed in a number of human cancers [35-37] and shows in some cases oncogene-like properties [3841]. It remains mysterious in what way eEF1A2, $98 \%$ similar and $92 \%$ identical to eEF1A1, which is specific for a definite tissue, may be related to the formation of tumor in the same tissue. 
The eEF1A1 and eEF1A2 isoforms are known to contain 462 and 463 amino acid residues correspondingly with 34 replacements and sole deletion of penultimate residue in eEF1A1. eEF1A1 has seven modified residues as eEF1A2 is characterized by four modified residues [42]. We supposed that even slight difference of primary sequences may cause significant differences of spatial structures of the eEF1A isoforms affecting, in its turn, the ability of one or another isoform to interact with protein partners which may result in the modification of its known functions and appearance of some new ones. The differential scanning microcalorimetry and circular dichroism in «near» and «far» UV regions were used to compare the spatial structures of two tissue-specific eEF1A isoforms. It appeared that the potentially oncogenic eEF1A2 isoform possessed a more compact spatial organization than eEF1A1, and the differences were revealed at the levels of both secondary and tertiary structure of proteins. These specificities of spatial organization may result in the exposure of functional sites in eEF1A2, capable of binding signal molecules, which may serve as one of the reasons for oncogenicity of this isoform.

Since tyrosine kinases are prominent players in cancer development, direct comparison of the ability of eEF1A1 and eEF1A2 to be involved in phosphoTyrspecific signalling processes could help to interpret cancer-related properties of eEF1A2. The ability of eEF1A1 and eEF1A2 to interact with $\mathrm{SH} 2$ and $\mathrm{SH} 3$ domains of different signalling molecules in vitro was compared as well as the levels of their tyrosine phosphorylation. To test if native eEF1A1 and eEF1A2 contain such modifications we probed the isolated eEF1A proteins with monoclonal antibodies specific to phosphorylated tyrosines. Actually, A2 isoform of mammalian translation factor eEF1A was found to display increased tyrosine phosphorylation and ability to interact with different signaling molecules [43] that may be connected with its oncogenic-like property. A possible role of tyrosine phosphorylation in providing the background for structural differences between the «extended» A1 isoform and the compact A2 isoform is discussed in [44]. In general dynamic changes in post-translational modifications play a central role in regulation of cell signaling in both normal and pathological processes and could be vital for organisms. Very often, the signaling processes comprise subsequent phosphorylation/dephosphorylation of the tyrosine, serine and threonine residues in regulatory proteins, which is a central subject of current phosphoproteomic studies and reviewed in [45].

The current knowledge about «structure-function» relationship in macromolecules gives grounds for considering one more reason of the functional difference between eEF1A1 and eEF1A2 that might lie in changes of the isoforms molecular dynamics. We used bioinformatics approach and determined by multiple MD simulation that eEF1A1 shows increased reciprocal flexibility of structural domains I and II and less average distance between the domains, while increased non-correlated diffusive atom motions within protein domains characterize eEF1A2. The divergence in the dynamic properties of eEF1A1 and eEF1A2 is caused by interactions of amino acid residues, that differ between the two variants, with neighboring residues and water environment. The main correlated motion of both protein isoforms is the change in proximity of domains I and II which can lead to disappearance of the gap between the domains and transition of the protein into a «closed» conformation.

Such a transition is reversible and the protein can adopt an «open» conformation again [42]. This finding is in line with our earlier experimental observation that the transition between «open» and «closed» conformations of eEF1A could be essential for binding of tRNA and/or other biological ligands. For example, the putative calmodulin-binding region Asn311-Gly327 is less flexible in eEF1A1 implying its increased affinity for calmodulin which is a messenger protein. The ability of eEF1A1 rather than eEF1A2 to interact with $\mathrm{Ca}^{2+} /$ calmodulin is shown experimentally in an ELISA-based test $[42,46]$.

These works are among the first studies suggesting that $98 \%$ similar isoforms of homologous proteins may have different spatial conformations [47] and molecular dynamics [42]. Therefore, not only the changes in the primary structure, revealed $e . g$. in the appearance of new domains, or in elimination or appearance of new sites of post-translational modifications, but also the changes in their spatial conformation are important for the functional divergence of the protein isoforms. These data will allow extending the direction of searching for multiple families of various isoproteins. 
One of the cardinal tasks is to discover the mechanisms of differential regulation of the eEF1A isoforms expression. As it was noted, that during postnatal period a switch from eEF1A1 to eEF1A2 expression occurs in the cardiac, muscle and neuronal tissues. This change of their expression is crucial, as the mice with a partial deletion of the gene die on the $28^{\text {th }}$ day after birth [33].

At cancerogenesis the appearance of EEF1A2 in nonspecific tissues and its overexpression in tumor tissues was found not to be a consequence of any multiplication of gene loci that might arise from chromosome instability, or from genetic and/or epigenetic changes [40, 48], thus suggesting the possibility of the regulation occurring at the post-transcriptional level. To solve the problem, at least partly, several model systems were used, including breast cancer progression [49] and myoblast differentiation [50]. The research on these two models was performed in close collaboration with laboratory of prof. A. Harel-Bellan. Despite high homology in an open reading frame $(\mathrm{ORF})$ region, $\mathrm{mRNAs}$ coding for eEF1A1 and eEF1A2 are different in their untranslated regions (UTR), suggesting a possibility of their dissimilar posttranscriptional regulation. To analyze the existence of cisacting motifs in the UTRs of EEF1A1/A2 mRNAs an ensemble of bioinformatic methods was applied to predict regulatory motifs in the UTRs of EEF1A1/A2 mRNAs.

Dual-luciferase reporter assay was also employed to detect post-transcriptional regulation of eEF1A1/A2 expression. Numerous regulatory motifs in the UTR of EEF1A1/A2 mRNAs were found bioinformatically, though, these mRNAs contain distinct motifs in the UTRs. The experimental evidence was obtained for the existence of negative regulation of EEF1A1 and positive regulation of EEF1A2 mRNA in the model of breast cancer development. The results suggest that in cancer the expression of EEF1A isoforms is regulated in a different way at post-transcriptional level and is controlled by different cellular signals [49].

Using immortalized human myoblasts cell line LHCN, we have shown the induction of isoform A2 of eEF1 during differentiation of myoblasts. The existence of transcriptional and post-transcriptional control of the above-mentioned process was confirmed. Downregulation of microRNAs, mir-661 and mir-744, that have binding sites in the 3'UTR of EEF1A2 mRNA, during differentiation suggests a potential role of microRNAs in the eEF1A2 induction during myoblast differentiation [50].

Next, we have examined the role of miRNAs in the control of eEF1A2 expression in the MCF7 cell line model. Our findings demonstrate that two miRNAs, miR663 and miR-744, target translation of EEF1A mRNA, and mediate inhibition of eEF1A2 expression on mRNA and protein level that results in down-regulation of MCF7 cells proliferation. Our data also show that the resveratrol-induced inhibition of breast cancer progression can be partially explained by a stimulatory effect of this treatment on miR-663 and miR-744 expression, which in turn leads to eEF1A2 downregulation (Submitted). A separate line of our investigations on eEF1A involvement in tumor formation was directed to understanding the prostate tumor-inducing oncogene (PTI-1) impact. PTI-1 presumably encoding a truncated form of eEF1A, was discovered as a gene overexpressed in prostate tumor samples and absent in normal tissues. The mechanism of PTI-1 oncogenicity remained obscure. We characterized N-terminus-truncated form of eEF1A as analogue of PTI- 1 oncogene product. The most significant difference between this analogue of PTI-1 and native eEF1A consists in decreased activity in cell-free translational system and increased ability to induce inaccuracy of translation [51].

However, despite the detection of the PTI-1 transcript in different cells and tissues, there are no reports so far about the presence of a protein product of this gene in the same samples [52]. That is why we put forward a new hypothesis of the PTI-1 oncogenicity based on the possibility of synthesis of another peptide from upstream open reading frame in the 5'UTR of the PTI-1 transcript in more favorable context for translation initiation than the main ORF.

Importantly, in such case this assumed peptide resembles the active center of relaxin, the peptide hormone involved in the prostate cancer progression [53]. However, as much as this idea is attractive it needs a credible experimental evidence.

We analyzed cancer-related behavior of the translation elongation factor $1 \mathrm{H}$ complex $(\mathrm{eEF} 1 \mathrm{H})$ and found the individual subunits can exist separately from the eEF1B complex in cancer tissues and that disintegration of eEF1B could be an important sign of cancer development. Nuclear localization of $\mathrm{B} \gamma$ in both normal 
and cancer tissues suggests its previously unknown nucleus-specific role in human cells [54].

The ribosome is a main body («soma») of the translational machine and its properties are of great importance for the effective and correct protein biosynthesis. Ribosomes from eukaryotes differ in their size, sequence, structure, and the ratio of protein to RNA from bacteria and archaea. However, there are principal common features determining molecular mechanisms of initiation, elongation and termination of polypeptide chains. One of them is a number of tRNA binding sites. In collaboration with the laboratory of prof. Kirrilov we were the first to show that in spite of considerable differences between prokaryotic and eukaryotic ribosomes they are similar in both the number of tRNA binding sites (namely the A, P and E sites) and their distribution between ribosomal subunits [55]. The $80 \mathrm{~S}$ ribosome was found to have two binding sites for aminoacyl-tRNA and peptidyl-tRNA and the third site formed by its 60S subunit for deacylated tRNA. The evidence was obtained that tRNA binding to the A and P sites of $80 \mathrm{~S}$ ribosomes and 40S subunits was a cooperative process. The affinity of tRNA for the A site of $80 \mathrm{~S}$ ribosome was shown to depend on the correct codon-anticodon pairing at the $\mathrm{P}$ site. This suggests that the cooperativity results from the codon-induced interaction of tRNA molecules bound at the $\mathrm{A}$ and $\mathrm{P}$ sites of $80 \mathrm{~S}$ ribosomes [56].

One more specific feature of $80 \mathrm{~S}$ ribosomes from higher eukaryotic organisms is an ability to hydrolyse ATP and GTP without the addition of soluble protein factors. ATPase seems to be an intrinsic activity of the $80 \mathrm{~S}$ ribosome though this phenomenon is not yet clarified completely. We revealed that as far as wide substrate specificity and possible participation in tRNA interaction with the ribosome are concerned, the ribosomal ATPase seems to be similar to EF-3 found in fungi [57]. Further research confirmed that the intrinsic ribosomal ATPase fulfills the same function as the essential third elongation factor EF-3, an ATPase in higher fungi, that facilitates the release of the deacylated tRNA from the E site of $80 \mathrm{~S}$ ribosome [58]. It is noteworthy that there is the reciprocal linkage between the A and $\mathrm{E}$ sites of outmost importance for accurate protein synthesis as the $\mathrm{E}$ site occupation induces a low affinity mode for tRNA binding to the A site and vice versa, occupation of the A site triggers the release of the E site-tRNA. In collabo- ration with K. Nierhaus this was found true for higher eukaryotic ribosomes which permits us to conclude that the allosteric interaction of $\mathrm{A}$ and $\mathrm{E}$ sites is universal since it has also been demonstrated in a bacterial and yeast systems [59].

However, in this work we discovered some essential differences in tRNA and mRNA binding capabilities of eukaryotic and bacterial ribosomes and their subunits. We also found that eukaryotic ribosomes bind tetracycline with an affinity 15 times lower than that of bacterial ribosomes. The drug does not affect enzymatic A site occupation of $80 \mathrm{~S}$ ribosomes in contrast to non-enzymatic tRNA binding to the A site. Both observations explain the relative resistance of eukaryotic ribosomes to this antibiotic. Recently, multiparticle cryoelectron microscopy and single-molecule FRET investigations of the mammalian pre-translocation complex conducted in collaboration with Christian Spahn's laboratory revealed critical distinctions in the structural and energetic features of bacterial and mammalian ribosomes, providing a mechanistic basis for divergent translation regulation strategies and species-specific antibiotic action [60].

In summary, our long-term research revealed some essential specific properties of both translational machine and process of protein biosynthesis itself in higher eukaryotes. Among them of special importance are adaptation of tRNAs and ARSs cellular pools to the synthesis of specific proteins and its importance for the translation regulation, compartmentalization of the the protein synthetic apparatus, channeling of aa-tRNA/tRNA in elongation cycle via formation of non-orthodox multimacromolecular complexes, different features of eEF1A isoforms and discovery of micro-RNA-mediated regulation of proto-oncogenic A2 isoform in cancer cells, eEF1A2 crystal form and its description, characterization of spatial structure of eEF1A2 and 80 S ribosomes, discovery of the third tRNA binding site on mammals ribosomes and the allosteric interaction of the $80 \mathrm{~S}$ ribosomal A and E sites.

Part of the significant results were obtained in close collaboration with Profs. S. Kirillov (former USSR), M. Deutscher (USA), K. Nierhaus (Germany), M. Mirande (France), I. Serdyuk (RF), and A. Harel-Bellan (France) to whom we are very thankful for support and encouragement. 
А. В. Сльська, Б. С. Негруцький, В. Ф. Шалак, А. А. Вісловух, Д. О. Власенко, О. В. Новосильна, Т. О. Лукаш, М. В. Верем'єва

Особливості біосинтезу білка у вищих евкаріотів

Резюме

В огляд підсумовано найвагоміші результати більш ніж сорокалітніх досліджень особливостей трансляції у вищих евкаріотів, 3-поміж яких: 1) відкриття адаптації клітинних пулів тРНК $i$ аміноаиил-тРНК синтетаз (АРСаз) до синтезу специифічних білків і модуляції швидкості елонгації рідкісними ізоакцепторними тРНК; 2) визначення шапероноподібних властивостей компонентів апарату транслячії (рибосом і фактора елонгачї еЕF1A), характеристика високомолекулярних комплексів АРСаз; 3) встановлення функиіональної компартменталізаиії, у тому числі каналювання тРНК в евкаріотних клітинах; 4) з'ясування молекулярних механізмів каналювання, що відбувається за посередництвом різних неканонічних комплексів, які містять еЕF1A, $\mathrm{mPHK} i$ APCази; 5) характеристика кристалічної структури еЕF1A2; 6) порівняння просторової організації, молекулярної динаміки, тирозинового фосфорилювання $і$ здатності до взаємодії з різними білками - партнерами ізоформ еЕF1A1 і еЕF1A2; 7) виявлення ролі мікроРНК у контролі експресії протоонкогенної ізоформи еЕF1A2 в ракових клітинах; 8) вивчення спричинених раком змін комплексу факторів елонгації трансляції еЕF1Н і механізмів дї онкогену PTI-1; 9) відкриття третього сайта зв 'язування тРНК у рибосомах ссавиів та алостеричної взаємодї̈ A- $i$ E-сайтів 80 - рибосоми.

Ключові слова: біосинтез білка, вищі евкаріоти, тРНК, аміноацил-тРНК синтетази, компартменталізація, каналювання, еЕF1А, мікроРНК, еЕF1Н, РTI-1, 80 S рибосоми.

А. В. Ельская, Б. С. Негруикий, В. Ф. Шалак, А. А. Висловух, Д. О. Власенко, А. В. Новосильная, Т. О. Лукаш, М. В. Веремьева

Особенности биосинтеза белка у высших эукариот

Резюме

В обзоре суммированы наиболее значимые результаты более чем сорокалетнего исследования особенностей транслячии у высших эукариотов, среди них: 1) открытие адаптации клеточных пулов тРНК и аминоацил-тРНК синтетаз (АРСаз) к синтезу специифических белков и модуляичи скорости элонгации редкими изоакиепторными тРНК; 2) определение шапероноподобных свойств компонентов аппарата трансляции (рибосом и фактора элонгации еЕF1A) и характеристика высокомолекулярных комплексов АРСаз; 3) установление функииональной компартментализации, включающей каналирование тРНК в эукариотных клетках; 4) выяснение молекулярных механизмов каналирования, опосредованного неканоническими комплексами, содержащими еЕF1А, aзы; 5) характеристика кристаллической структуры еЕF 1A2; 6) сравнение пространственной организации, молекулярной динамики, тирозинового фосфорилирования и способности к взаимодействию с различными белками - партнерами изоформ еЕF1A1 и еЕF1A2; 7) выявление роли микроРНК в контроле экспрессии протоонкогенной изоформы еЕF1 22 в раковых клетках; 8) изучение связанных с раком изменений комплекса факторов элонгации трансляиии еЕF1Н и механизмов действия онкогена PTI-1; 9) открытие третьего сайта связывания тРНК в рибосомах млекопитаюших и аллостерического взаимодействия $A$ - и Е-сайтов на 80 рибосомах.

Ключевые слова: биосинтез белка, высшие эукариоты, тРНК, аминоацил-тРНК синтетазы, компартментализация, каналирова-ние, еЕF1А, микроРНК, еЕF1Н, PTI-1, 80S рибосомы.

\section{REFERENCES}

1. El'skaya A. V., Matsuka G. Kh. Contribution to the alteration in the set of individual tRNA in the mammary gland cells depending upon quality of synthesized protein // Ukr. Biochem. J.1968.-40, N 2.-P. 120-124.

2. Matsuka G. Kh., El'skaya A. V., Kovalenko M. I., Korneluk A. I. Transport ribonucleic acids.-Kiev: Nauk. dumka, 1976.-219 p.

3. El'skaya A. V., Matsuca G., Matiash U., Nazarenko I., Semenova $N$. tRNA and aminoacyl-tRNA synthetases during differentiation and various functional states of Mammary Gland // Biochim. Biophys. Acta.-1971.-247, N 2.-P. 430-440.

4. El'skaya A. . Adapter-modification hypothesis of the regulatory function of tRNA // Mol. Biol.-1971.-7, N 13.-P. 152-165.

5. El'skaya A. V., Starodub N. F., Potapov A. P., Kovalenko M. I., Ovcharenko G. V., Obolenskaya M. U., Ivanov L. L. Regulation of protein biosynthesis in eukaryotes.-Kiev: Nauk. dumka, 1990.$280 \mathrm{p}$.

6. El'skaya A. V., Turkovskaya G.V., Rachkov A. E., Starodub N. F. Role of tRNA in regulation of specific protein biosynthesis // Dokl. AN USSR.-1982.-7, N 3.-P. 64-67.

7. El'skaya A. V. Regulation of protein synthesis in higher eukaryotes: Facts and hypotheses // Mol. Biol.-1999.-33, N 6.-P. 10431053.

8. Gudzera O. I., El'skaya A. V., Ovcharenko G. V., Ivanov L. L., Baturina I. D., Matsuka G. Kh. Purufication and properties of Leucyl-tRNA synthetase from the cow mammary gland // Mol. Biol.-1979.-13, N 3.-P. 550-557.

9. Gudzera O. I., El'skaya A. V., Ovcharenko G. V., Kovalenko M. I., Matsuka G. Kh. Study of the aminoacyl-tRNA-synthetases upon mammary gland differentiation // Mol. Biol.-1978.-20, N 10.-P. 12-22.

10. Yaremchuk A. D., El'skaya A. V. Biological activity of tRNA, aminoacyl-tRNA-synthetases and composition of their high-molecular complexes in the rat regenerating liver // Ukr. Biochem. J.-1983.-55, N 4.-P. 363-367.

11. Duran R. V., Hall M. N. Leucyl-tRNA synthetase: double duty in amino acid sensing // Cell Res.-2012.-22, N 8.-P. 1207-1209.

12. Bandyopadhyay A. K., Deutscher M. P. Complex of aminoacyltransfer RNA synthetases // J. Mol. Biol.-1971.-60, N 1.P. 113-122.

13. Ivanov L. L., Yaremchuk A. D., Stapulyenis R. R., Tamulyavichus A. I., Buldakova O. V., Kovalenko M. I., El'skaya A. V. Study of high-molecular organization of eukaryotic aminoacyltRNA synthetases // Ukr. Biochem. J.-1986.-58, N 6.-P. 368-371.

14. Rodovitus G. A., Ivanov L. L., Lukoshevichius L. I, Kovalenko M. I., El'skaya A. V. Aminoacyl-tRNA synthetases of the rat liver under experimental myocardial infarction // Dokl. AN USSR.1982.-4, N 2.-P. 63-65.

15. Yaremchuk A. D., Goncharov N. I., Bogdanaite O. D., Tarasevichene L. V., Kondratyuk T. P., El'skaya A. V. Aminoacyl-tRNA synthetases complexes under sharp changes in protein biosynthesis // Dokl. AN USSR.-1984.-3, N 3.-P. 82-85.

16. Yaremchuk A. D., Tarasevichene L. E., Kondratjuk T. P., El'skaya A. $V$. Aminoacyl-tRNA synthetases and their high-molecular complexes from rat regenerating liver // Mol. biol.-1984.-18, N 5.-P. 1336-1341.

17. Lzhanova A. T., Fedorov A. N., Ovchinnikov L. P. AminoacyltRNA synthetases of rabbit reticulocytes with and without the ability to bind high- $\mathrm{M}_{\mathrm{r}}$ RNA // FEBS Lett.-1982.-144, N 4.-P. 149-153.

18. Ivanov L. L., Martinkus Z., Kharchenko O. V., Sana S., Lukoshevichius L., Prashkevichius A., El'skaya A. V. Subcellular distri- 
bution and properties of rabbit liver aminoacyl-tRNA synthetases under myocardial ischemia // Mol. Cell. Biochem.-1993.125, N 9.-P. 105-114.

19. Kaminska M., Havrylenko S., Decottignies P., Le Marechal P., Negrutskii B., Mirande M. Dynamic organization of aminoacyltRNA synthetase complexes in the cytoplasm of human cells // J. Biol. Chem.-2009.-284, N 20.-P. 13746-13754.

20. Havrylenko S., Legouis R., Negrutskii B., Mirande M. Caenorhabditis elegans evolves a new architecture for the multi-aminoacyl-tRNA synthetase complex // J. Biol. Chem.-2011.-286, N 32.-P. 28476-28487.

21. Negrutskii B. S., Deutscher M. P. Channeling of aminoacyl-tRNA for protein synthesis in vivo // Proc. Natl Acad. Sci. USA.1991.-88, N 11.-P. 4991-4995.

22. Negrutskii B. S., Stapulionis R., Deutscher M. P. Supramolecular organization of the mammalian translation system // Proc. Natl Acad. Sci. USA.-1994.-91, N 3.-P. 964-968.

23. Negrutskii B. S., Budkevich T. V., Shalak V. F., Turkovskaya G. $V$., El'skaya A. V. Rabbit translation elongation factor 1 alpha stimulates the activity of homologous aminoacyl-tRNA synthetase // FEBS Lett.-1996.-382, N 1-2.-P. 18-20.

24. Lukash T. O., Turkivska H. V., Negrutskii B. S., El'skaya A. V. Chaperone-like activity of mammalian elongation factor eEF1A: renaturation of aminoacyl-tRNA synthetases // Int. J. Biochem. Cell Biol.-2004.-36, N 7.-P. 1341-1347.

25. Petrushenko Z. M., Negrutskii B. S., Ladokhin A. S., Budkevich T. V., Shalak V.F., El'skaya A. V. Evidence for the formation of an unusual ternary complex of rabbit liver EF-1alpha with GDP and deacylated tRNA // FEBS Lett.-1997.-407, N 1.-P. 13-17.

26. Negrutskii B. S., Shalak V. F., Kerjan P., El'skaya A. V., Mirande $M$. Functional interaction of mammalian valyl-tRNA synthetase with elongation factor EF-1alpha in the complex with EF1H // J. Biol. Chem.-1999.-274, N 8.-P. 4545-4550.

27. Petrushenko Z. M., Budkevich T. V., Shalak V. F., Negrutskii B. $S$., El'skaya A. $V$. Novel complexes of mammalian translation elongation factor eEF1A.GDP with uncharged tRNA and aminoacyl-tRNA synthetase. Implications for tRNA channeling // Eur. J. Biochem.-2002.-269, N 19.-P. 4811-4818.

28. Negrutskii B. S., El'skaya A. V. Eukaryotic translation elongation factor 1 alpha: structure, expression, functions, and possible role in aminoacyl-tRNA channeling // Prog. Nucleic Acid Res. Mol. Biol.-1998.-60.-P. 47-78.

29. Negrutskii B. S., El'skaia A. V. Functional compartmentation of the translation apparatus and channeling of tRNA/aminoacyltRNA in cells of higher eukaryotes // Mol. Biol.-2001.-35, N 4.P. 702-707.

30. Andersen G. R., Pedersen L., Valente L., Chatterjee I., Kinzy T. G., Kjeldgaard M., Nyborg J. Structural basis for nucleotide exchange and competition with tRNA in the yeast elongation factor complex eEF1A:eEF1Balpha // Mol. Cell.-2000.-6, N 5.P. 1261-1266.

31. Yaremchuk A., Shalak V. F., Novosylna O. V., Negrutskii B. S., Crepin T., El'skaya A. V., Tukalo M. Purification, crystallization and preliminary X-ray crystallographic analysis of mammalian translation elongation factor eEF1A2 // Acta Crystallogr. Sect. F Struct. Biol. Cryst. Commun.-2012.-68, Pt 3.-P. 295-297.

32. Budkevich T. V., Timchenko A. A., Tiktopulo E. I., Negrutskii B. S., Shalak V. F., Petrushenko Z. M., Aksenov V. L., Willumeit R., Kohlbrecher J., Serdyuk I. N., El'skaya A. V. Extended conformation of mammalian translation elongation factor $1 \mathrm{~A}$ in solution // Biochemistry.-2002.-41, N 51.-P. 15342-15349.

33. Newbery H. J., Loh D. H., O'Donoghue J. E., Tomlinson V. A., Chau Y. Y., Boyd J. A., Bergmann J. H., Brownstein D., Abbott C. $M$. Translation elongation factor eEF1A2 is essential for post-weaning survival in mice // J. Biol. Chem.-2007.-282, N 39.-P. 28951-28959.

34. Duttaroy A., Bourbeau D., Wang X. L., Wang E. Apoptosis rate can be accelerated or decelerated by overexpression or reduction of the level of elongation factor-1 alpha // Exp. Cell. Res.1998.-238, N 1.-P. 168-176.

35. Cao H., Zhu Q., Huang J., Li B., Zhang S., Yao W., Zhang Y. Regulation and functional role of eEF1A2 in pancreatic carcinoma // Biochem. Biophys. Res. Commun.-2009.-380, N 1.-P. 11-16.

36. Pinke D. E., Kalloger S. E., Francetic T., Huntsman D. G., Lee $J$. M. The prognostic significance of elongation factor eEF1A2 in ovarian cancer // Gynecol. Oncol.-2008.-108, N 3.-P. 561-568.

37. Scaggiante B., Dapas B., Bonin S., Grassi M., Zennaro C., Farra R., Cristiano L., Siracusano S., Zanconati F., Giansante $C$., Grassi G. Dissecting the expression of EEF1A1/2 genes in human prostate cancer cells: the potential of EEF1A2 as a hallmark for prostate transformation and progression // Br. J. Cancer.-2012.-106, N 1.-P. 166-173.

38. Lee J. M. The role of protein elongation factor eEF1A2 in ovarian cancer // Reprod. Biol. Endocrinol.-2003.-1.-P. 69.

39. Anand N., Murthy S., Amann G., Wernick M., Porter L. A., Cukier I. H., Collins C., GrayJ. W., Diebold J., Demetrick D. J., Lee J. $M$. Protein elongation factor EEF1A2 is a putative oncogene in ovarian cancer // Nat. Genet.-2002.-31, N 3.-P. 301-305.

40. Tomlinson V. A., Newbery H. J., Wray N. R., Jackson J., Larionov A., Miller W. R., Dixon J. M., Abbott C. M. Translation elongation factor eEF1A2 is a potential oncoprotein that is overexpressed in two-thirds of breast tumours // BMC cancer.-2005.5.-P. 113.

41. Zhu H., Lam D. C., Han K. C., Tin V. P., Suen W. S., Wang E., Lam W. K., Cai W. W., Chung L. P., Wong M. P. High resolution analysis of genomic aberrations by metaphase and array comparative genomic hybridization identifies candidate tumour genes in lung cancer cell lines // Cancer Lett.-2007.-245, N 1-2.-P. 303-314.

42. Kanibolotsky D. S., Novosyl'na O. V., Abbott C. M., Negrutskii B. $S$. Multiple molecular dynamics simulation of the isoforms of human translation elongation factor $1 \mathrm{~A}$ reveals reversible fluctuations between «open» and «closed» conformations and suggests specific for eEF1A1 affinity for $\mathrm{Ca}^{2+}$-calmodulin // BMC Struct. Biol.-2008.-8.-P. 4.

43. Panasyuk G., Nemazanyy I., Filonenko V., Negrutskii B., El'skaya $A$. $V$. A2 isoform of mammalian translation factor eEF1A displays increased tyrosine phosphorylation and ability to interact with different signalling molecules // Int. J. Biochem. Cell Biol.2008.-40, N 1.-P. 63-71.

44. Negrutskii B., Vlasenko D., El'skaya A. From global phosphoproteomics to individual proteins: the case of translation elongation factor eEF1A // Expert Rev. Proteomics.-2012.-9, N 1.P. 71-83

45. Mayya V., Han D. K. Phosphoproteomics by mass spectrometry: insights, implications, applications and limitations // Expert Rev. Proteomics.-2009.-6, N 6.-P. 605-618.

46. Timchenko A., Serdyuk I., Negrutskii B., Novosylna A., Prituzhalov E., Kimura K., Kihara H. Study of complex formation between calmodulin and two isoforms of rabbit elongation factor eEF1-A by SAXS method // Photon Factory Activity Report.2008.-25, part B.-P. 247.

47. Novosylna A. V., Timchenko A. A., Tiktopulo E. I., Serdyuk I. N., Negrutskii B. S., El'skaya A. V. Characterization of physical properties of two isoforms of translation elongation factor 1A // Biopolym. Cell.-2007.-23, N 5.-P. 386-390.

48. Tomlinson V. A., Newbery H. J., Bergmann J. H., Boyd J., Scott D., Wray N. R., Sellar G. C., Gabra H., Graham A., Williams A. R., Abbott C. M. Expression of eEF1A2 is associated with clear 
cell histology in ovarian carcinomas: overexpression of the gene is not dependent on modifications at the EEF1A2 locus // Br. J. Cancer.-2007.-96, N 10.-P. 1613-1620.

49. Vislovukh A. A., Naumovets M. G., Kovalenko M. I., Groisman R. S., Groisman I. S., Negrutskii B. S., El'skaya A. V. Isoforms of elongation factor eEF1A may be differently regulated at posttranscriptional level in breast cancer progression // Biopolym. Cell.-2013.-29, N 1.-P. 55-63.

50. Vislovukh A. A., Groisman I. S., El'skaya A. V., Negrutskii B. S., Polesskaya A. N. Transcriptional and post-transcriptional control of eEF1A2 expression during myoblast diffrerentiation // Biopolym. Cell.-2012.-28, N 6.-P. 456-460.

51. Pogribna A. P., Negrutskii B. S., El'skaya A. V. Removal of part of the eEF1A GTP binding domain induced translation errors in vitro // Biopolym. Cell.-2006.-22, N 3.-P. 186-191.

52. Mansilla F., Hansen L. L., Jakobsen H., Kjeldgaard N. O., Clark B. F., Knudsen C. R. Deconstructing PTI-1: PTI-1 is a truncated, but not mutated, form of translation elongatin factor 1A1, eEF1A1 // Biochim. Biophys. Acta.-2005.-1727, N 2.-P. 116-124.

53. Vislovukh A. A., Shalak V. F., Savytskyi O. V., Kovalenko N. I., Gralievska N. L., Negrutskii B. S., El'skaya A. V. PTI-1: novel way to oncogenicity // Biopolym. Cell.-2012.-28, N 5.-P. 404-410.

54. Veremieva M., Khoruzhenko A., Zaicev S., Negrutskii B., El'skaya $A$. Unbalanced expression of the translation complex eEF1 subunits in human cardioesophageal carcinoma // Eur. J. Clin. Invest.2011.-41, N 3.-P. 269-276.
55. Rodnina M. V., El'skaya A. V., Semenkov Yu. P., Kirillov S. V. Number of tRNA binding sites on $80 \mathrm{~S}$ ribosomes and their subunits // FEBS Lett.-1988.-231, N 1.-P. 71-74.

56. Rodnina M. V., El'skaya A. V., Semenkov Y. P., Kirillov S. V. Interaction of tRNA with the A and $\mathrm{P}$ sites of rabbit-liver $80 \mathrm{~S}$ ribosomes and their 40S subunits // Eur. J. Biochem.-1989.-185, N 3.-P. 563-568.

57. Rodnina M. V., Serebryanik A. I., Ovcharenko G. V., El'skaya A. $V$. ATPase strongly bound to higher eukaryotic ribosomes // Eur. J. Biochem.-1994.-225, N 1.-P. 305-310.

58. El'skaya A. V., Ovcharenko G. V., Palchevskii S. S., Petrushenko Z. M., Triana-Alonso F. J., Nierhaus $K$. $H$. Three tRNA binding sites in rabbit liver ribosomes and role of the intrinsic ATPase in $80 \mathrm{~S}$ ribosomes from higher eukaryotes // Biochemistry.1997.-36, N 34.-P. 10492-10497.

59. Budkevich T. V., El'skaya A. V., Nierhaus K. H. Features of $80 \mathrm{~S}$ mammalian ribosome and its subunits // Nucleic Acids Res.2008.-36, N 14.-P. 4736-4744.

60. Budkevich T., Giesebrecht J., Altman R. B., Munro J. B., Mielke T., Nierhaus K. H., Blanchard S. C., Spahn C. M. Structure and dynamics of the mammalian ribosomal pretranslocation complex // Mol. Cell.-2011.-44, N 2.-P. 214-224.

Received 30.12.12 